\title{
Estimating evapotranspiration in Puerto Rico ${ }^{1,2}$
}

\author{
Eric W. Harmsen ${ }^{3}$, Megh R. Goyal ${ }^{4}$ and Salvio Torres-Justiniano ${ }^{5}$
}

J. Agric. Univ. P.R. 86(1-2):35-54 (2002)

\begin{abstract}
The United Nations Food and Agriculture Organization (FAO) has recommended the Penman-Monteith method as the single method for estimating reference evapotranspiration throughout the world. A disadvantage of the method, however, is its relatively high data requirement. Measurements of wind speed, humidity (or dew point temperature) and radiation tend to be the least available of the required parameters; therefore, the FAO has presented estimation procedures for these parameters. The purpose of this study was to evaluate estimation procedures for climate data to be used in the Penman-Monteith method for estimating long-term daily reference evapotranspiration, and to verify the accuracy of the procedures at four locations in Puerto Rico. Comparison of reference evapotranspiration determined by using the estimated and measured climate data shows reasonably good agreement. The methods presented in this paper are potentially valuable for calculating the long-term average daily reference evapotranspiration at any location in Puerto Rico. An example is provided to illustrate the use of the proposed estimation procedures for climate parameters. This study presents a comparison of reference evapotranspiration calculated by the Penman-Monteith method, with estimates previously made by using the Hargreaves-Samani method, for thirty-four locations in Puerto Rico. In addition, estimated peak evapotranspiration from the Soil Conservation Service (SCS) (now Natural Resources Conservation Service) Irrigation Guide for the Caribbean Area, the SCS Blaney-Criddle method and the Penman-Monteith method were compared for six vegetable crops at three locations in Puerto Rico. The results suggest that some irrigation systems may have been under-designed in terms of flow capacity in Puerto Rico.
\end{abstract}

Key words: evapotranspiration, reference evapotranspiration, crop water use, Penman-Monteith, climatology, Puerto Rico

${ }^{1}$ Manuscript submitted to Editorial Board 9 October 2001.

${ }^{2}$ The authors are grateful for financial support from the USDA Higher Education Program-Hispanic Serving Institutions (Undergraduate and High School Experiences in Environmental Issues, University of Puerto Rico Center for Investigation and Development No. 533521), We are also grateful to the University of Puerto Rico Agricultural Experiment Station Special Project (SP-347) for its financial support. We would like to thank Dr. Amos Winter of the Caribbean Atmospheric Research Center for providing us with climate data for San Juan, Aguadilla, Mayagüez and Ponce.

${ }^{3}$ Assistant Professor, Agricultural and Biosystems Engineering Department, University of Puerto Rico, P.O. Box 9030, Mayagüez, PR 00681. email: eric_harmsen@cca.uprm.edu.

${ }^{4}$ Professor, General Engineering Department, University of Puerto Rico, Mayagüez, PR 00681.

${ }^{5}$ Undergraduate Research Assistant, Department of Agronomy, University of Puerto Rico, Mayagüez, PR 00681. 


\title{
RESUMEN
}

\author{
Estimando evapotranspiración en Puerto Rico
}

\begin{abstract}
La Organización de Alimentos y Agricultura de las Naciones Unidas (FAO, por sus siglas en inglés) ha recomendado el método de Penman-Monteith como el único método de calculación que se debería usar para estimar evapotranspiración de referencia a través del mundo. Sin embargo, una desventaja del método es que requiere un número alto de datos. Las medidas de la velocidad del viento, la humedad (o la temperatura de punto de rocío) y la radiación tienden a ser los parámetros requeridos más difíciles de obtener; por ello, la FAO ofrece procedimientos alternos de estimación para estos parámetros. El propósito de este estudio fue evaluar los procedimientos de estimación de los datos del clima requeridos por el método de Penman-Monteith para estimar la evapotranspiración de referencia promedio diaria a largo plazo y verificar la exactitud de los procedimientos en cuatro zonas de Puerto Rico. Se encontró una alta correlación entre la evapotranspiración de referencia calculada con los datos estimados (FAO) y la calculada con los datos observados del clima. Los métodos presentados son potencialmente valiosos para calcular la evapotranspiración de referencia promedio diaria en cualquier zona de Puerto Rico. Se provee un ejemplo para ilustrar el uso del procedimiento propuesto para estimar parámetros del clima. Se presenta una comparación de la evapotranspiración de referencia calculada por el método de Penman-Monteith y resultados estimados previamente por el método de Hargreaves-Samani para 34 zonas en Puerto Rico. Además, el estimado máximo de evapotranspiración de la Guía de Riego del Servicio de Conservación de Suelos (SCS) (ahora Servicio de Conservación de Recursos Naturales) para el Área del Caribe, el método de Blaney-Criddle (SCS) y él método de Penman-Monteith se compararon para seis vegetales en tres localidades en Puerto Rico. Los resultados indican que algunos sistemas de riego no tienen suficiente capacidad para suplir agua en Puerto Rico.
\end{abstract}

\section{INTRODUCTION}

Water consumptive use or evapotranspiration (ET) by crops is affected by air temperature, solar radiation, wind speed, humidity, and crop characteristics. Evapotranspiration can be estimated from the relation $\mathrm{ET}=\mathrm{K}_{\mathrm{c}} \mathrm{ET}_{\mathrm{o}}$, where $\mathrm{K}_{\mathrm{c}}$ is a crop coefficient, and $\mathrm{ET}_{\mathrm{o}}$ is the reference evapotranspiration. The Penman-Monteith method has been recommended as the best method for estimating $\mathrm{ET}_{\mathrm{o}}$ (Allen et al., 1998). This recommendation was based on comprehensive studies which compared several evapotranspiration calculation methods with weighing lysimeter data (Jensen et al., 1990; Choisnel et al., 1992). These studies found the Penman-Monteith method to give better results than the SCS Blaney-Criddle and Hargreaves-Samani methods, both of which are used extensively in Puerto Rico. Harmsen et al. (2001) reported large differences between the SCS Blaney-Criddle method and the Penman-Monteith method in a study that compared seasonal consumptive use for pumpkin and onion at two locations in Puerto Rico. The maximum observed differences were on the order of $100 \mathrm{~mm}$ per season. No comparisons have been made between the Hargreaves-Samani and Penman-Monteith methods in Puerto Rico. 
The objectives of this study were 1) to select prediction methods for estimating long-term average daily minimum temperature $\left(\mathrm{T}_{\min }\right)$, maximum temperature $\left(\mathrm{T}_{\max }\right)$, dew point temperature $\left(\mathrm{T}_{\text {dew }}\right)$, solar radiation $\left(\mathrm{R}_{\mathrm{s}}\right)$ and wind speed (U) for Puerto Rico; 2 ) to verify the ability to estimate reference evapotranspiration $\left(\mathrm{ET}_{0}\right)$ using estimated climate data at four locations where long-term measured climate data were available; and 3) to compare the Penman-Monteith-estimated reference evapotranspiration with estimates previously made by the Hargreaves-Samani method at thirty-four locations in Puerto Rico.

\section{MATERLALS AND METHODS}

Estimation procedures for long-term daily climate data were derived from the literature. To evaluate the appropriateness of the procedures, comparisons were made of $\mathrm{ET}_{0}$ calculated by using estimated and measured climate data (i.e., $\mathrm{T}_{\text {min }}, \mathrm{T}_{\mathrm{max}}, \mathrm{T}_{\text {dew }} \mathrm{R}_{\mathrm{s}}$ and $\mathrm{U}$ ) at four locations in Puerto Rico: San Juan, Aguadilla, Mayagüez and Ponce. These sites represent the northeast, northwest, west, and south of Puerto Rico, respectively. These sites were selected because relatively complete climatic data sets existed for these locations.

T'wo primary sources of long-term climate data for Puerto Rico are Local Climatological Data (LCD) sheets published by the National Oceanic and Atmospheric Administration (NOAA) and the International Station Meteorological Climate Summary (ISMCS) (National Climate Data Center, 1992). The LCDs provide temperature data for approximately 40 locations in Puerto Rico. The LCDs also include detailed weather data for San Juan, which include wind speed, relative humidity and hours of daily sunshine. This was the sole source of long-term average daily radiation data for Puerto Rico. The ISMCS provides longterm average daily $\mathrm{T}_{\min }, \mathrm{T}_{\max }, \mathrm{T}_{\mathrm{dew}}$ and $\mathrm{U}_{10}$ (subscript refers to the height of the wind speed measurement above the ground) for airports at Aguadilla, Mayagüez, Ponce, San Juan and the Roosevelt Roads Navy Base at Ceiba. Unfortunately, the long-term Roosevelt Roads $\mathrm{T}_{\min }, \mathrm{T}_{\max }$ and $\mathrm{T}_{\text {dew }}$ data were found to be in error and therefore could not be used in this study. Additional long-term average daily wind speed data $\left(\mathrm{U}_{0.58}\right)$ were available from Aguirre, Lajas, Isabela, Río Piedras, Gurabo, Corozal, Fortuna (Juana Díaz), Yabucoa and Adjuntas.

\section{RESULTS AND DISCUSSION}

Proposed Climate Estimation Procedures for Puerto Rico

In this section, estimation procedures for $T_{\min }, T_{\max }, T_{\text {dew }}, R_{s}$ and $U$ are presented: 


\section{Minimum and Maximum Air Temperature}

Goyal et al. (1988) developed regression equations for minimum and maximum long-term average daily air temperatures for Puerto Rico based on surface elevation. Table 1 lists the regression coefficients for the daily average minimum and maximum temperatures in Puerto Rico by month. The regression equations have the following general form:

$$
\mathrm{T}=\mathrm{A}+\mathrm{BZ}
$$

where $\mathrm{T}$ is temperature $\left({ }^{\circ} \mathrm{C}\right), \mathrm{A}$ and $\mathrm{B}$ are regression coefficients and $\mathrm{Z}$ is elevation $(\mathrm{m})$ above mean sea level. Regression equations were derived with temperature data from Climatography of the United States No. 86-45 for Puerto Rico.

\section{Dew Point Temperature}

The FAO (Allen et al., 1998) has reported that $\mathrm{T}_{\text {dew }}$ can be estimated on the basis of the daily minimum air temperature. A correction factor based on local conditions should be added to the minimum temperature. Therefore, $\mathrm{T}_{\mathrm{dew}}$ can be estimated in Puerto Rico from the following equation:

$$
\mathrm{T}_{\text {dew }}=\mathrm{T}_{\text {min }}+\mathrm{K}_{\text {corr }}
$$

where $\mathrm{K}_{\text {corr }}$ is a temperature correction factor in degrees $\left({ }^{\circ} \mathrm{C}\right)$, listed in Table 2. The other variables have been defined previously.

TABLE 1.-Relationships among temperatures ( $T$ ) and elevations (Z) for Puerto Rico

\begin{tabular}{|c|c|c|c|c|c|c|}
\hline \multirow[b]{2}{*}{ Month } & \multicolumn{3}{|c|}{$\begin{array}{l}\text { Mean daily maximum } \\
\text { temperatures, }{ }^{\circ} \mathrm{C}\end{array}$} & \multicolumn{3}{|c|}{$\begin{array}{l}\text { Mean daily minimum } \\
\text { temperatures, }{ }^{\circ} \mathrm{C}\end{array}$} \\
\hline & A & $B,-10^{-5}$ & $x^{2}$ & A & $B,-10^{-5}$ & $\mathrm{r}^{2}$ \\
\hline Jan. & 29.24 & 770 & 0.73 & 18.58 & 544 & 0.44 \\
\hline Feb. & 29.37 & 752 & 0.72 & 18.37 & 558 & 0.46 \\
\hline Mar: & 30.08 & 711 & 0.71 & 18.71 & 590 & 0.48 \\
\hline Apr. & 30.59 & 687 & 0.71 & 19.90 & 686 & 0.63 \\
\hline May & 31.16 & 707 & 0.76 & 21.23 & 608 & 0.63 \\
\hline June & 31.76 & 686 & 0.73 & 21.92 & 577 & 0.59 \\
\hline July & 32.07 & 717 & 0.64 & 22.14 & 591 & 0.58 \\
\hline Aug. & 32.12 & 682 & 0.75 & 22.21 & 585 & 0.58 \\
\hline Sep. & 32.12 & 696 & 0.79 & 21.95 & 586 & 0.62 \\
\hline Oct. & 31.84 & 705 & 0.79 & 21.48 & 553 & 0.59 \\
\hline Nov. & 30.89 & 706 & 0.75 & 20.68 & 562 & 0.55 \\
\hline Dec. & 29.83 & 744 & 0.73 & 19.52 & 547 & 0.47 \\
\hline
\end{tabular}
(Goyal et al., 1988). ${ }^{\text {. }}$

${ }^{\mathrm{T}} \mathrm{T}=\mathrm{A}+\mathrm{BZ}$, where $\mathrm{T}=$ temperature, ${ }^{\circ} \mathrm{C} ; \overline{\mathrm{Z}}=$ elevation above mean sea level, $\mathrm{m} ; \mathrm{A}$ and $B$ are regression coefficients; and $\mathrm{r}^{2}$ is the coefficient of determination. 
On the basis of the analysis presented in the next section, correction factors $\left(\mathrm{K}_{\text {corr }}\right)$ were calibrated for three of the six Climate Divisions of Puerto Rico as defined by NOAA, and are presented in Table 2. Figure 1 shows the Climate Divisions for Puerto Rico. The $-2.5^{\circ} \mathrm{C}$ correction factor for Division 2 is consistent with $\left(\mathrm{T}_{\min }-\mathrm{T}_{\text {dew }}\right)$ data for similar arid regions reported by Allen et al. (1998). No long-term average $\mathrm{T}_{\text {dew }}$ data were available for Climate Divisions 3,5 and 6. Therefore, these Divisions were assigned a value of $0^{\circ} \mathrm{C}$ similar to that of Division 4 (humid conditions). Table 2 recommends using a value for $\mathrm{K}_{\text {corr }}$ of 1.0 if the $T_{\text {dew }}$ is estimated by using estimated $\mathrm{T}_{\min }$ data, and a value of $-1.5^{\circ} \mathrm{C}$ if $\mathrm{T}_{\text {dew }}$ is estimated by using measured $\mathrm{T}_{\min }$ data. The reason is that for the four locations evaluated in this study the regression equations (Table 1) underestimated $\mathrm{T}_{\text {min }}$, thus causing an underestimation of $\mathrm{T}_{\text {dew }}$ 'To correct this problem, a value of $\mathrm{K}_{\text {corr }}$ equal to $0.5^{\circ} \mathrm{C}$ should be used when $\mathrm{T}_{\text {dew }}$ is estimated from estimated $\mathrm{T}_{\min }$ data.

\section{Wind Speed}

No equation exists for estimating wind speed. The FAO recommends that wind speed be estimated from nearby weather stations, or as a preliminary measure the worldwide average of $2 \mathrm{~m} / \mathrm{sec}$ can be used. The Penman-Monteith method is based on a wind speed measured $2 \mathrm{~m}$ above the ground and is referred to as $\mathrm{U}_{2}$ (subscript refers to the height of the wind speed measurement above the ground). Wind speeds that are collected at heights other than $2 \mathrm{~m}$ above the ground can be adjusted to the $\mathrm{U}_{2}$ value by using an exponential relationship. Table 3 presents daily average wind speeds for Puerto Rico. These wind speeds were estimated by averaging station data within the Climate Divisions established by NOAA.

TABLE 2.--Temperature correction Factor $K_{\text {corr }}$ used in Equation 2 for Climate Divisions ${ }^{t}$ within Puerto Rico.

\begin{tabular}{llcc}
\hline Climate Division $^{1}$ & \multicolumn{1}{c}{1} & 2 & $3,4,5,6$ \\
\hline $\mathrm{K}_{\text {corr }}\left({ }^{\circ} \mathrm{C}\right)$ & $\begin{array}{l}1.0 \text { if } \mathrm{T}_{\text {dew }} \text { is estimated using estimated } \\
\mathrm{T}_{\text {nin }} \text { data }\end{array}$ & -2.9 & 0 \\
& $\begin{array}{l}-1.5 \text { if } \mathrm{T}_{\text {dew }} \text { is estimated using measured } \\
\end{array}$ & & \\
& $\mathrm{T}_{\min }$ data
\end{tabular}

${ }^{1}$ See Figure 1 for climate divisions. 


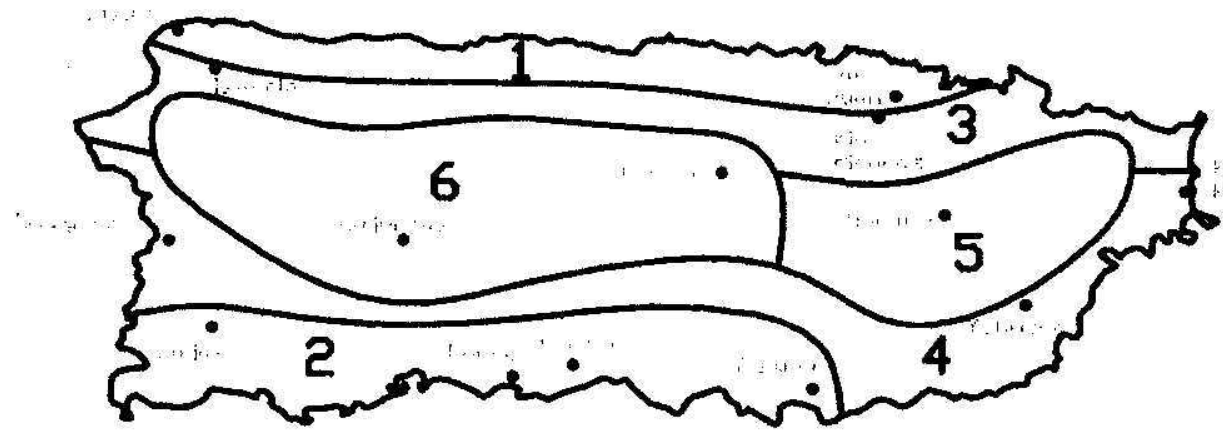

FIGURE 1. Climate Divisions of Puerto Rico: 1, North Coastal; 2, South Coastal; 3, Northern Slopes; 4, Southern Slopes; 5, Eastern Interior; and 6, Western Interior.

\section{Radiation}

The FAO recommends that solar radiation be estimated by using the following equation for islands:

$$
R_{s}=\left(0.7 R_{a}-b\right)
$$

where $R_{s}$ is solar radiation, $b$ is an empirical constant, equal to $4 \mathrm{MJ} /$ $\mathrm{m}^{2} /$ day and $R_{\mathrm{a}}$ is the incoming extraterrestrial radiation. Table 4 lists values of $R_{a}$ by month and for latitudes applicable to Puerto Rico. The equations used to develop Table 4 are presented in Allen et al. (1998).

Equation 3 is limited to elevations of less than $100 \mathrm{~m}$ above sea level. Therefore, for higher elevations, in the interior areas of Puerto

TABLE 3.-Average daily wind speeds $\left(U_{2}\right)$ by month and Climate Division ${ }^{1}$ within Puerto Rico.

\begin{tabular}{|c|c|c|c|c|c|c|c|c|c|c|c|c|}
\hline \multirow{2}{*}{$\begin{array}{l}\text { Climate } \\
\text { division }{ }^{1}\end{array}$} & \multicolumn{12}{|c|}{ Average daily wind speeds at $2 \mathrm{~m}$ above the ground $(\mathrm{m} / \mathrm{s})^{2}$} \\
\hline & Jan & Feb & Mar & Apr & May & June & July & Aug & Sept & Oct & Nov & Dec \\
\hline 1 & 2.7 & 2.8 & 3.0 & 2.9 & 2.6 & 2.6 & 2.9 & 2.7 & 2.1 & 1.9 & 2.2 & 2.6 \\
\hline 2 & 1.8 & 2.0 & 2.2 & 2.1 & 2.2 & 2.4 & 2.4 & 2.1 & 1.7 & 1.5 & 1.4 & 1.5 \\
\hline 3 & 2.2 & 2.4 & 2.6 & 2.4 & 2.2 & 2.4 & 2.7 & 2.5 & 2.0 & 1.8 & 2.0 & 2.3 \\
\hline 4 & 1.8 & 2.0 & 2.1 & 2.1 & 2.0 & 2.0 & 2.0 & 1.8 & 1.6 & 1.6 & 1.6 & 1.6 \\
\hline 5 & 1.1 & 1.3 & 1.4 & 1.5 & 1.6 & 1.7 & 1.6 & 1.3 & 1.1 & 0.9 & 0.9 & 0.9 \\
\hline 6 & 1.3 & 1.5 & 1.5 & 1.5 & 1.6 & 1.8 & 1.8 & 1.5 & 1.2 & 1.1 & 1.0 & 1.0 \\
\hline
\end{tabular}

${ }^{1}$ See Figure 1 for climate divisions.

${ }^{2}$ Averages are based on San Juan and Aguadilla for Div. 1; Ponce, Aguirre, Fortuna and Lajas, for Div. 2; Isabela and Río Piedras for Div. 3; Mayagüez, Roosevelt Rd. and Yabucoa for Div. 4; Gurabo for Div. 5; and Corozal and Adjuntas for Div. 6. Measured wind speeds were adjusted to the wind speed $2 \mathrm{~m}$ above the ground $\left(\mathrm{U}_{2}\right)$ using the following equation: $\mathrm{U}_{2}=\left(4.87 \mathrm{U}_{\mathrm{z}}\right) /[\ln (67.8 \mathrm{z}-5.42)]$, where $\mathrm{U}_{\mathrm{z}}$ in $\mathrm{m} / \mathrm{sec}$ is the wind speed at height $\mathrm{z}$ in meters above the ground. 
TABLE 4.-Extraterrestrial radiation by month and latitude within Puerto Rico

\begin{tabular}{lccccccc}
\hline & \multicolumn{7}{c}{ Extraterrestrial radiation, $R_{\mathrm{a}}\left(\mathrm{MJ} / \mathrm{m}^{2} / \mathrm{day}\right)^{1}$} \\
\cline { 2 - 8 } & \multicolumn{7}{c}{ Latitude (decimal degrees $\mathrm{N})$} \\
Month & 17.90 & 18.00 & 18.10 & 18.20 & 18.30 & 18.40 & 18.50 \\
\hline Jan & 27.90 & 27.85 & 27.80 & 27.74 & 27.69 & 27.64 & 27.58 \\
Feb & 31.36 & 31.32 & 31.27 & 31.23 & 31.19 & 31.14 & 31.10 \\
Mar & 35.33 & 35.30 & 35.28 & 35.25 & 35.23 & 35.20 & 35.18 \\
Apr & 38.03 & 38.02 & 38.02 & 38.02 & 38.01 & 38.01 & 38.01 \\
May & 39.02 & 39.03 & 39.04 & 39.06 & 39.07 & 39.09 & 39.10 \\
June & 39.07 & 39.09 & 39.12 & 39.14 & 39.16 & 39.19 & 39.21 \\
July & 38.91 & 38.93 & 38.95 & 38.97 & 38.99 & 39.01 & 39.03 \\
Aug & 38.30 & 38.31 & 38.31 & 38.32 & 38.32 & 38.33 & 38.33 \\
Sep & 36.38 & 36.36 & 36.35 & 36.33 & 36.32 & 36.31 & 36.29 \\
Oct & 32.91 & 32.88 & 32.84 & 32.81 & 32.77 & 32.74 & 32.70 \\
Nov & 29.10 & 29.05 & 29.01 & 28.96 & 28.91 & 28.86 & 28.81 \\
Dec & 26.89 & 26.84 & 26.78 & 26.73 & 26.67 & 26.61 & 26.56 \\
\hline
\end{tabular}

${ }^{1}$ Mega-joules per square meter per day.

Rico, where the ocean does not moderate air temperatures as much as along the low altitude coastal areas, the Hargreaves radiation formula can be used:

$$
\mathrm{R}_{\mathrm{s}}=\mathrm{k}_{\mathrm{Rs}}\left(\mathrm{T}_{\max }-\mathrm{T}_{\min }\right)^{1 / 2} \mathrm{R}_{\mathrm{a}}
$$

where $k_{R s}$ is an adjustment factor equal to 0.19 . The other variables have been previously defined.

\section{Comparison of ET with Measured and Estimated Data}

This section compares calculated reference evapotranspiration $\left(\mathrm{ET}_{0}\right)$ based on measured and estimated climate parameters. The $\mathrm{ET}_{\mathrm{o}}$ based on measured data will be referred to as $\mathrm{ET}_{\text {om }}$, and the $\mathrm{ET}_{0}$ based on estimated data will be referred to as $\mathrm{ET}_{\mathrm{oe}}$. Figures 2 through 5 show the calculated $\mathrm{ET}_{\mathrm{o}}$ based on measured and estimated $\mathrm{T}_{\min }$ and $\mathrm{T}_{\text {max }}, \mathrm{T}_{\text {dew }} \mathrm{U}_{2}$ and $\mathrm{R}_{8}$, respectively. Estimated parameters were obtained from Tables 1 , 2 and 3 and equations 1,2 and 3. Equation 3 was used (instead of equation 4) because all of the locations being considered are at elevations of less than $100 \mathrm{~m}$. Ponce airport wind speeds were markedly higher than the nearby Fortuna Agricultural Experiment Station wind speeds, even after adjustment for height measurement and converting 24-hour measurements taken at the Experiment Station to daytime wind speeds. Therefore, measured wind speeds for Ponce were taken as the arithmetic mean of the Ponce airport and the Fortuna Experiment Station. 


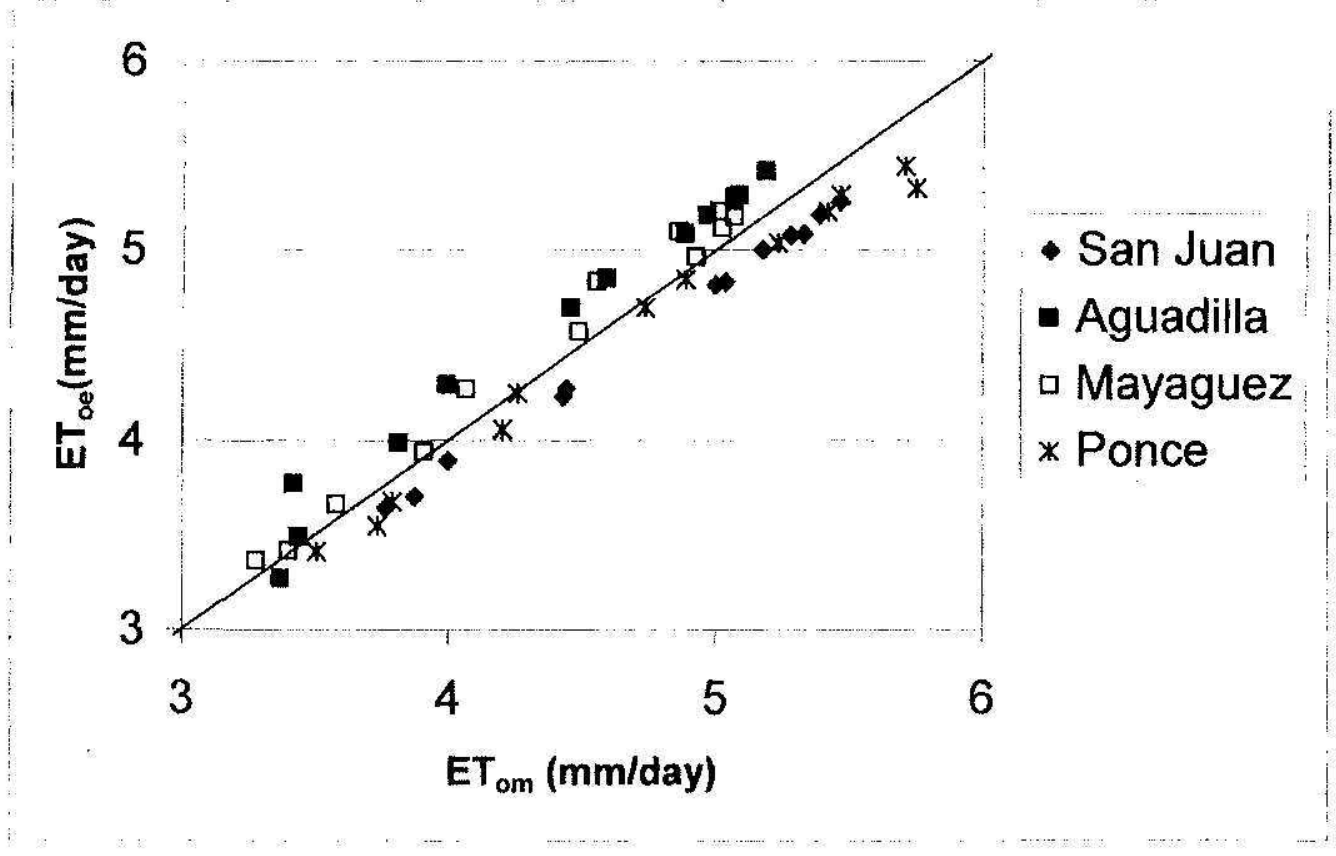

FIGURE 2. Comparison of reference evapotranspiration $\left(\mathrm{ET}_{0}\right)$ calculated with measured data (subscript $\mathrm{m}$ ) and estimated minimum and maximum temperature $\left(\mathrm{T}_{\min }\right.$ and $\mathrm{T}_{\max }$ ) data (subscript $\mathrm{e}$ ).

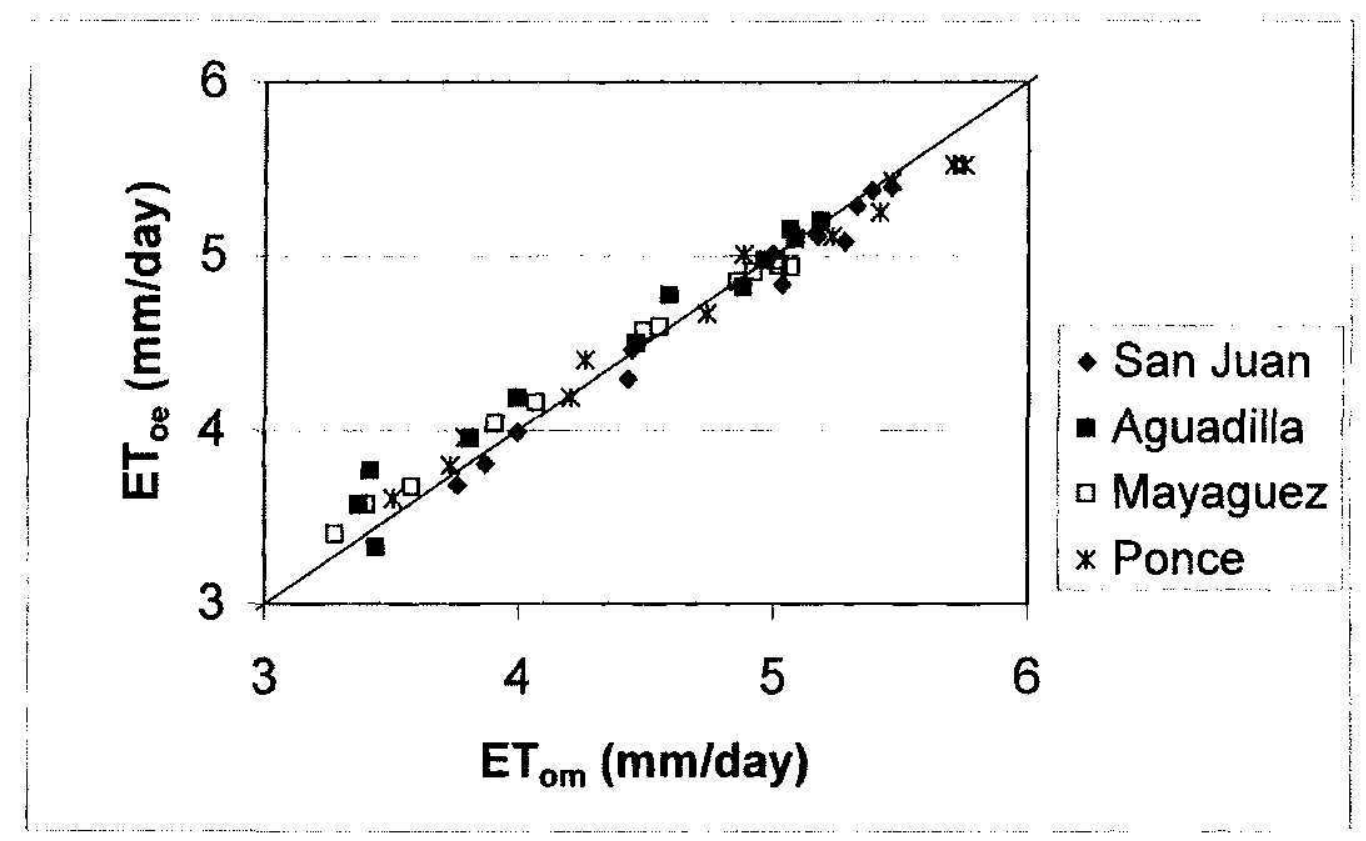

FIGURE 3. Comparison of reference evapotranspiration (ET) calculated with measured data (subscript $\mathrm{m}$ ) and estimated dew point temperature $\left(\mathrm{T}_{\text {dew }}\right.$ ) data (subscript $\mathrm{e}$ ). $\mathrm{K}_{\text {corr }}$ was set to -1.5 for Climate Division 1 Sites. 


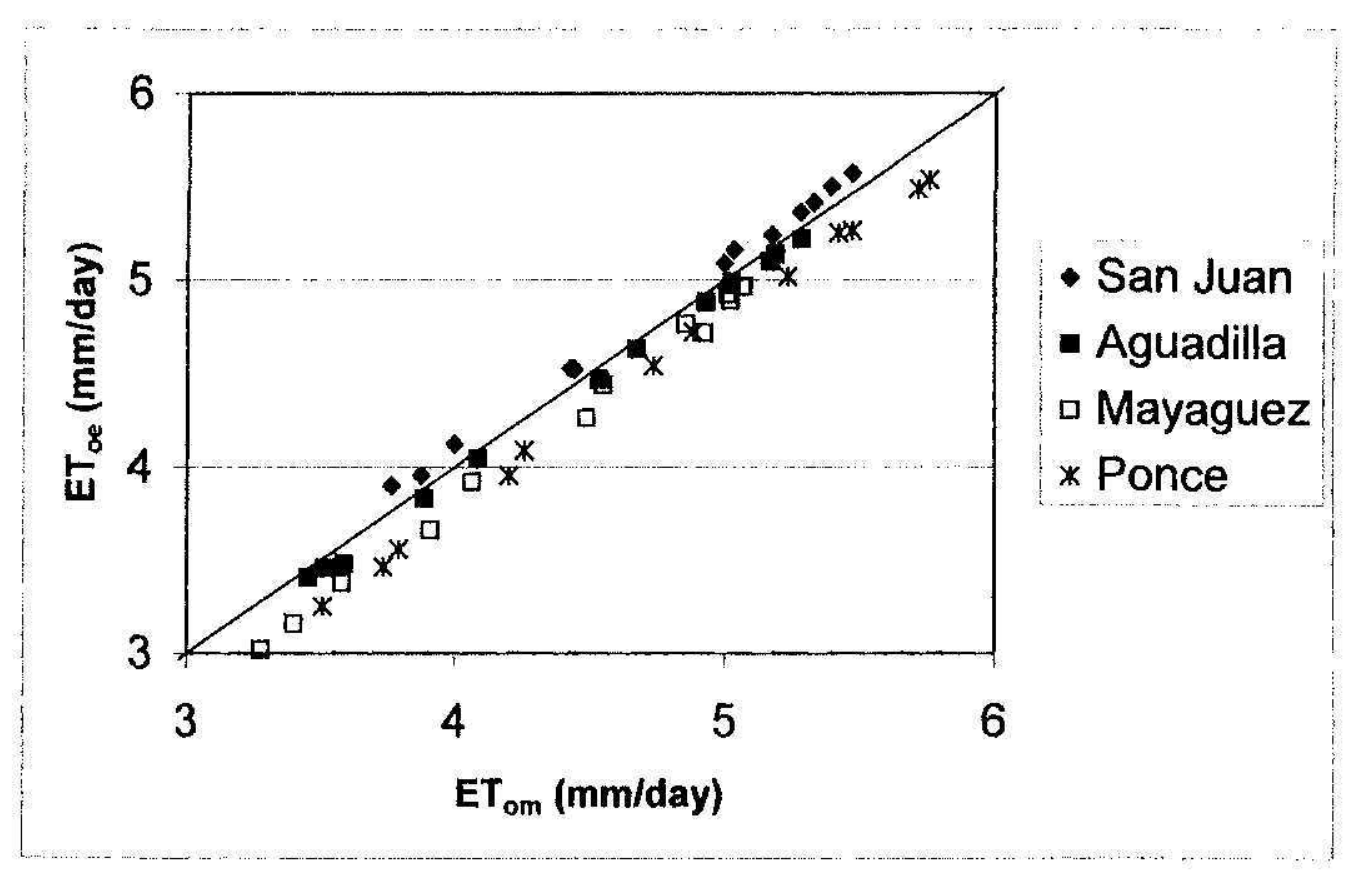

FIGURE 4. Comparison of reference evapotranspiration ( $\mathrm{ET}_{\mathrm{o}}$ ) calculated with measured data (subscript $m$ ) and estimated wind speed $\left(\mathrm{U}_{2}\right)$ data (subscript e).

The comparisons of $\mathrm{ET}_{\mathrm{om}}$ and $\mathrm{ET}_{\mathrm{oe}}$, shown in Figures 2 through 5 , indicate reasonably good agreement with some under $(-)$ and overestimations $(+)$ as noted below:

- Values for $\mathrm{ET}_{\mathrm{oe}}$ for Ponce, based on estimated $\mathrm{T}_{\min }$ and $\mathrm{T}_{\max }$ values, resulted in slight underestimations relative to $\mathrm{ET}_{\mathrm{om}}$ at high values of $\mathrm{ET}_{0}$ (Figure 2). The maximum underestimation was $-0.43 \mathrm{~mm} /$ day for Ponce during June. The maximum overestimation was $0.36 \mathrm{~mm} / \mathrm{d}$ for Aguadilla in November.

- Values of $\mathrm{ET}_{\text {oe }}$, based on estimated $\mathrm{T}_{\text {dew }}$ were in fairly good agreement with $\mathrm{ET}_{\text {om }}$ for all locations (Figure 3). The maximum error was $+0.35 \mathrm{~mm} /$ day for Mayagüez during January. The maximum underestimate was $-0.23 \mathrm{~mm} /$ day for San Juan during the months of March and April. Note that, based on instructions given in Table 2 , the $\mathrm{K}_{\text {corr }}$ value used was $-1.5^{\circ} \mathrm{C}$, because the values of $\mathrm{T}_{\min }$ were measured (not estimated).

- $\mathrm{ET}_{\mathrm{oe}}$ based on estimated values of wind speed $\left(\mathrm{U}_{2}\right)$, were generally in good agreement relative to $\mathrm{ET}_{\text {om }}$ (Figure 4). The maximum observed error was $-0.27 \mathrm{~mm} /$ day (underestimate) for Ponce in January. The maximum overestimate was +0.13 $\mathrm{mm}$ /day for San Juan in November. 


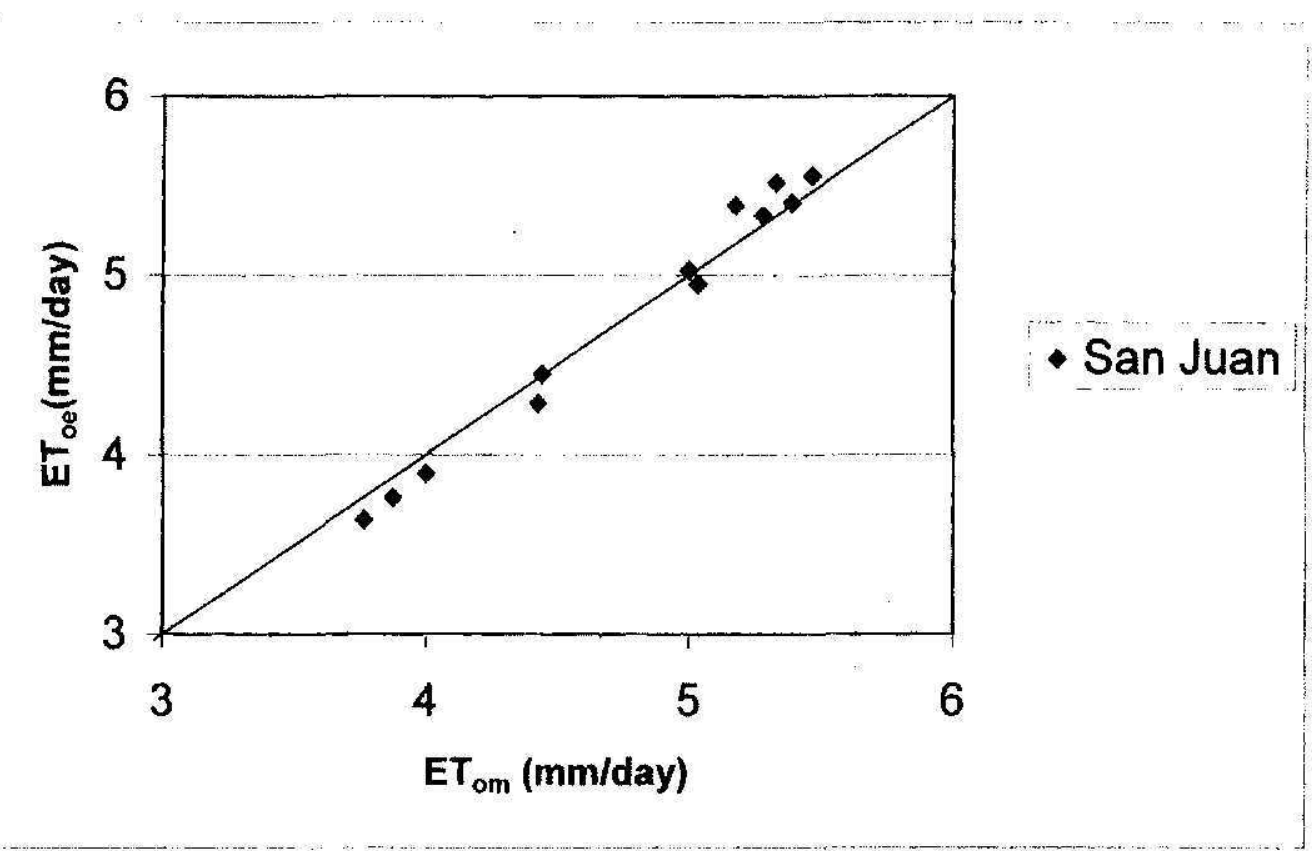

FIGURE 5. Comparison of reference evapotranspiration (ET $)$ calculated with measured data (subscript $m$ ) and estimated solar radiation $\left(R_{s}\right)$ data (subscript $e$ ).

- Measured radiation was available only for San Juan. Figure 5 indicates good agreement between $\mathrm{ET}_{\mathrm{oe}}$, based on equation 3 , and $\mathrm{ET}_{\mathrm{om}}$. The maximum under- and overestimates were -0.14 $\mathrm{mm} /$ day (February) and $+0.21 \mathrm{~mm} /$ day (May), respectively.

Figure 6 compares $\mathrm{ET}_{\text {om }}$ and $\mathrm{ET}_{\mathrm{oe}}$ based on all parameters estimated simultaneously. ET oe for Aguadilla was overestimated for all months relative to $\mathrm{ET}_{\mathrm{om}}$, whereas $\mathrm{ET}_{\mathrm{oe}}$ for San Juan was underestimated for all months. It is interesting to note that both Aguadilla and San Juan are in the same Climate Division (Figure 1). The maximum error was 0.51 $\mathrm{mm} /$ day for Aguadilla during November. The maximum negative error was $-0.29 \mathrm{~mm} /$ day for San Juan during February. A linear regression of the data shown in Figure 6 resulted in a coefficient of determination $\left(r^{2}\right)$ equal to 0.93 .

\section{Example Application}

With the climate estimation procedures, reference evapotranspiration was estimated for the following conditions at Dos Bocas, Arecibo, PR: elevation: $60 \mathrm{~m}$; latitude: $18^{\circ} 20^{\prime}$ (18.33 decimal degrees). Table 5 gives the estimated climate data and reference evapotranspiration for January through December. Minimum and maximum temperatures were calculated with data from Table 1. Dos Bocas is in Climate Divi- 


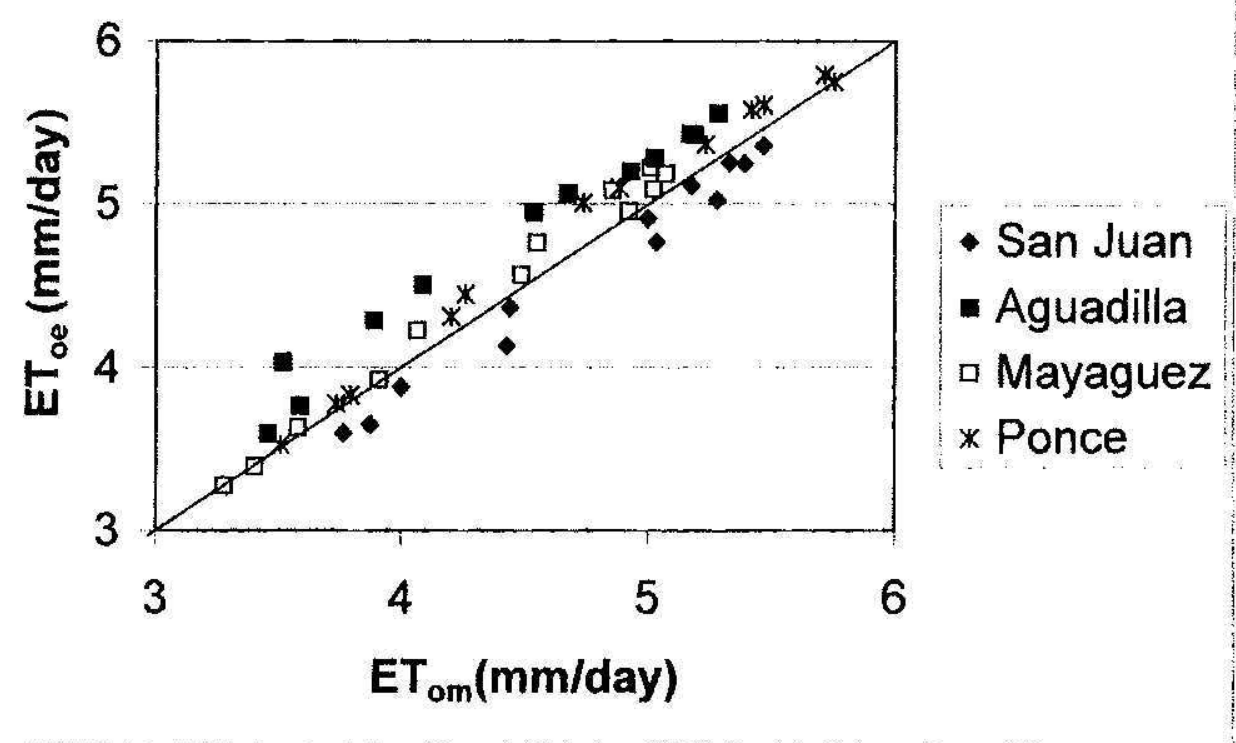

FIGURE 6. Comparison of reference evapotranspiration $\left(\mathrm{ET}_{\mathrm{o}}\right)$ calculated with measured data (subscript $\mathrm{m}$ ) and estimated data for all climate parameters (subscript $\mathrm{e}$ ). $\mathrm{K}_{\mathrm{corr}}$ was set to 0.5 for Climate Division 1 locations.

sion 6; therefore, as per Table 2, dew point temperature was taken as the minimum temperature (i.e., $\mathrm{K}_{\text {corr }}=0^{\circ} \mathrm{C}$ ). Wind speeds were obtained from Table 3 for Climate Division 6 . Values of $R_{a}$ (obtained from Table 4) have been included in Table 5.

Reference evapotranspiration was calculated by using the Penman Monteith method as described in Allen et al. (1998). The calculation procedure was implemented via an Excel spreadsheet. Alternatively, the reference evapotranspiration could have been calculated by using the computer program CROPWAT (Clarke, 1998). This program is available free of charge on the Internet.

Comparison of Estimated Reference Evapotranspiration at Thirty-four Locations in Puerto Rico

Using the Samani-Hargreaves method (Hargreaves and Samani, 1985), Goyal et al. (1988) estimated reference evapotranspiration at thirty-four locations in Puerto Rico. This section presents estimates based on the Penman-Monteith method. The two approaches will be compared.

Table 6 lists the Penman-Monteith-estimated reference evapotranspirations for the thirty-four locations considered by Goyal et al. (1988). This table indicates the Climate Division for each site, on the basis of 
TABL, 5. - Estimated climate data and reference evapotranspiration for Dos Bocas, PR.

\begin{tabular}{lcccccccccccc}
\hline Montl & Jan & Feb & Mar & Apr & May & June & July & Aug & Sept & Oct & Nov & Dec \\
\hline $\mathrm{T}_{\text {max }}{ }^{\circ} \mathrm{C}$ & 28.8 & 28.9 & 29.7 & 30.2 & 30.7 & 31.3 & 31.6 & 31.7 & 31.7 & 31.4 & 30.5 & 29.4 \\
$\mathrm{~T}_{\text {min }}{ }^{\circ} \mathrm{C}$ & 18.3 & 18.0 & 18.4 & 19.5 & 20.9 & 21.6 & 21.8 & 21.9 & 21.6 & 21.1 & 20.3 & 19.2 \\
$\mathrm{~T}_{\text {dew }}{ }^{\circ} \mathrm{C}$ & 18.3 & 18.0 & 18.4 & 19.5 & 20.9 & 21.6 & 21.8 & 21.9 & 21.6 & 21.1 & 20.3 & 19.2 \\
$\mathrm{U}_{2} \mathrm{~m} / \mathrm{s}$ & 1.3 & 1.5 & 1.5 & 1.5 & 1.6 & 1.8 & 1.8 & 1.5 & 1.2 & 1.5 & 1.0 & 1.0 \\
$\mathrm{R}_{\mathrm{a}}, \mathrm{MJ} /$ & 27.7 & 31.2 & 35.2 & 38.0 & 39.1 & 39.2 & 39.0 & 38.3 & 36.3 & 32.8 & 28.9 & 26.7 \\
$\mathrm{~m}^{2 / d a y}$ & & & & & & & & & & & & \\
$\mathrm{R}_{\mathrm{s}}, \mathrm{MJ} /$ & 15.4 & 17.8 & 20.7 & 22.6 & 23.4 & 23.4 & 23.3 & 22.8 & 21.4 & 18.9 & 16.2 & 14.7 \\
$\mathrm{~m}^{2 / d a y}$ & & & & & & & & & & & & \\
$\begin{array}{l}\mathrm{ET}_{\mathrm{o}} \text {, } \\
\mathrm{mm} / \text { day }\end{array}$ & 3.2 & 3.7 & 4.3 & 4.7 & 4.9 & 5.1 & 5.1 & 4.9 & 4.6 & 4.1 & 3.3 & 2.9 \\
\hline
\end{tabular}

Definitions: maximum daily air temperature $\left(\mathrm{T}_{\text {max }}\right) ;$ minimum daily air temperature $\left(\mathrm{T}_{\min }\right)$; dew point temperature $\left(\mathrm{T}_{\mathrm{dew}}\right)$; wind speed, measured at $2 \mathrm{~m}$ above the ground $\left(\mathrm{U}_{2}\right)$; extraterrestrial radiation $\left(\mathrm{R}_{\mathrm{a}}\right)$; solar radiation $\left(\mathrm{R}_{\mathrm{s}}\right)$; and long-term daily average reference evapotranspiration $\left(\mathrm{ET}_{0}\right)$.

which the $\mathrm{K}_{\text {corr }}$ and $\mathrm{U}_{2}$ values were selected from Tables 2 and 3. For locations with elevations less than or equal to $100 \mathrm{~m}$, and greater than $100 \mathrm{~m}, \mathrm{R}_{\mathrm{s}}$ was calculated by using equations 3 and 4 , respectively. Figure 7 shows the results of the comparison.

Figure 7 indicates positive and negative differences. The maximum positive difference [i.e., Hargreaves-Samani (H-S) minus PenmanMonteith (P-M)] was $0.92 \mathrm{~mm} /$ day during the month of November at the Juncos $1 \mathrm{E}$ station. On a monthly basis, this is equal to $27.5 \mathrm{~mm}$ or 1.1 inches of water. The minimum difference (i.e., negative difference) was $-0.75 \mathrm{~mm} /$ day during the month of June at Aguirre. On a monthly basis this is $-22.5 \mathrm{~mm}$ or -0.88 inches of water. Figure 7 indicates that while there was agreement between the two methods during many months at many locations, there were also many estimates which were not in agreement. One could reasonably ask the question: "Which method is more correct?" FAO recommends using the Penman-Monteith method over all other methods even when local data are missing. Studies have shown that using estimation procedures for missing data with the Penman-Monteith equation will generally provide more accurate estimates of $\mathrm{ET}_{0}$ than will other available methods requiring less input data (Allen et al., 1998).

Figure 8 shows a plot of the differences between $\mathrm{ET}_{0}$ calculated by the two methods (H-S minus P-M) by month, for the Juncos $1 \mathrm{E}$ and Aguirre stations. Maximum positive and negative differences were observed at these sites, respectively. If the Penman-Monteith method is taken as the standard ("correct") $\mathrm{ET}_{0}$, then it can be stated that the Hargreaves-Samani method overestimated $\mathrm{ET}_{0}$ at Juncos $1 \mathrm{E}$ and un- 


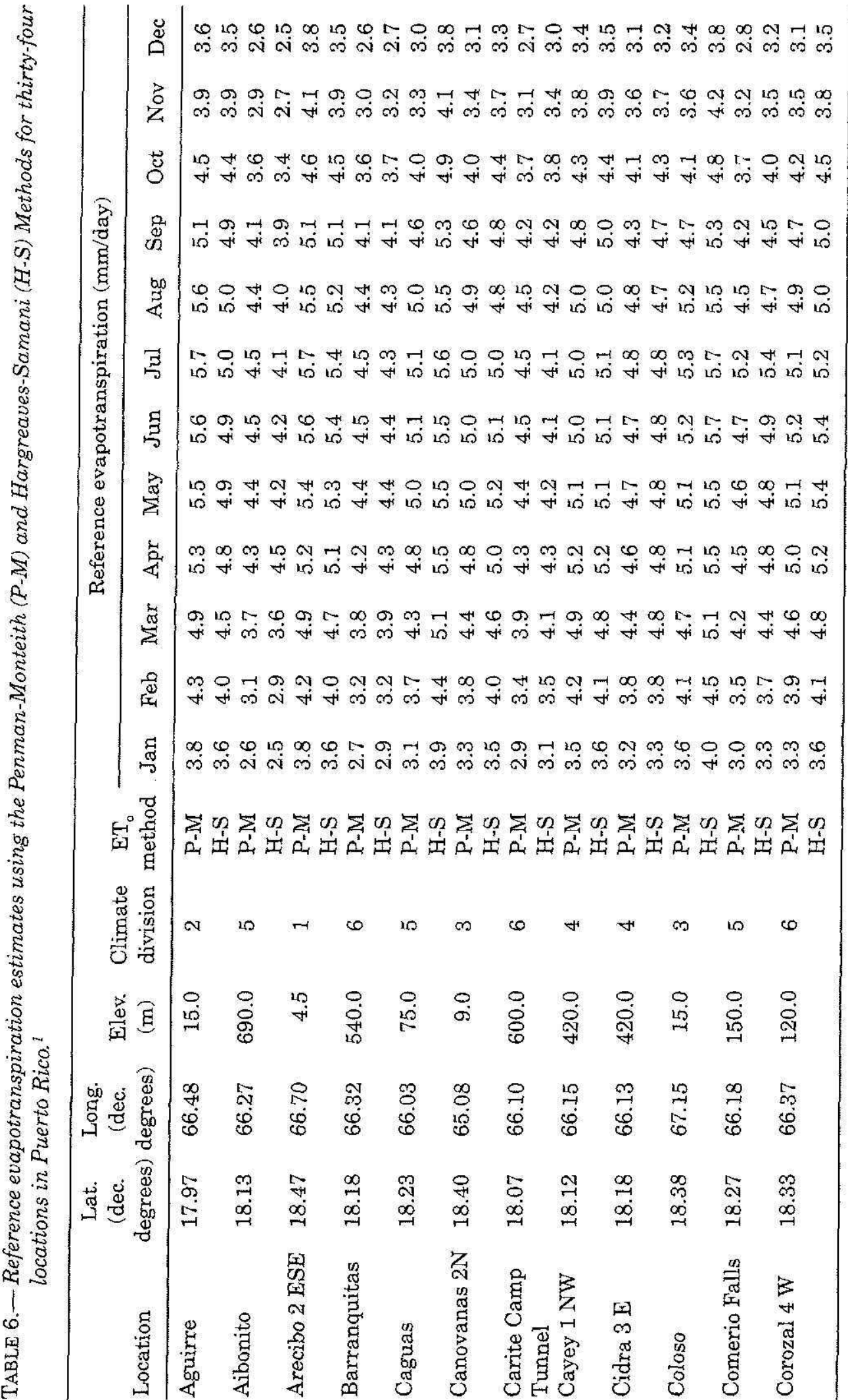




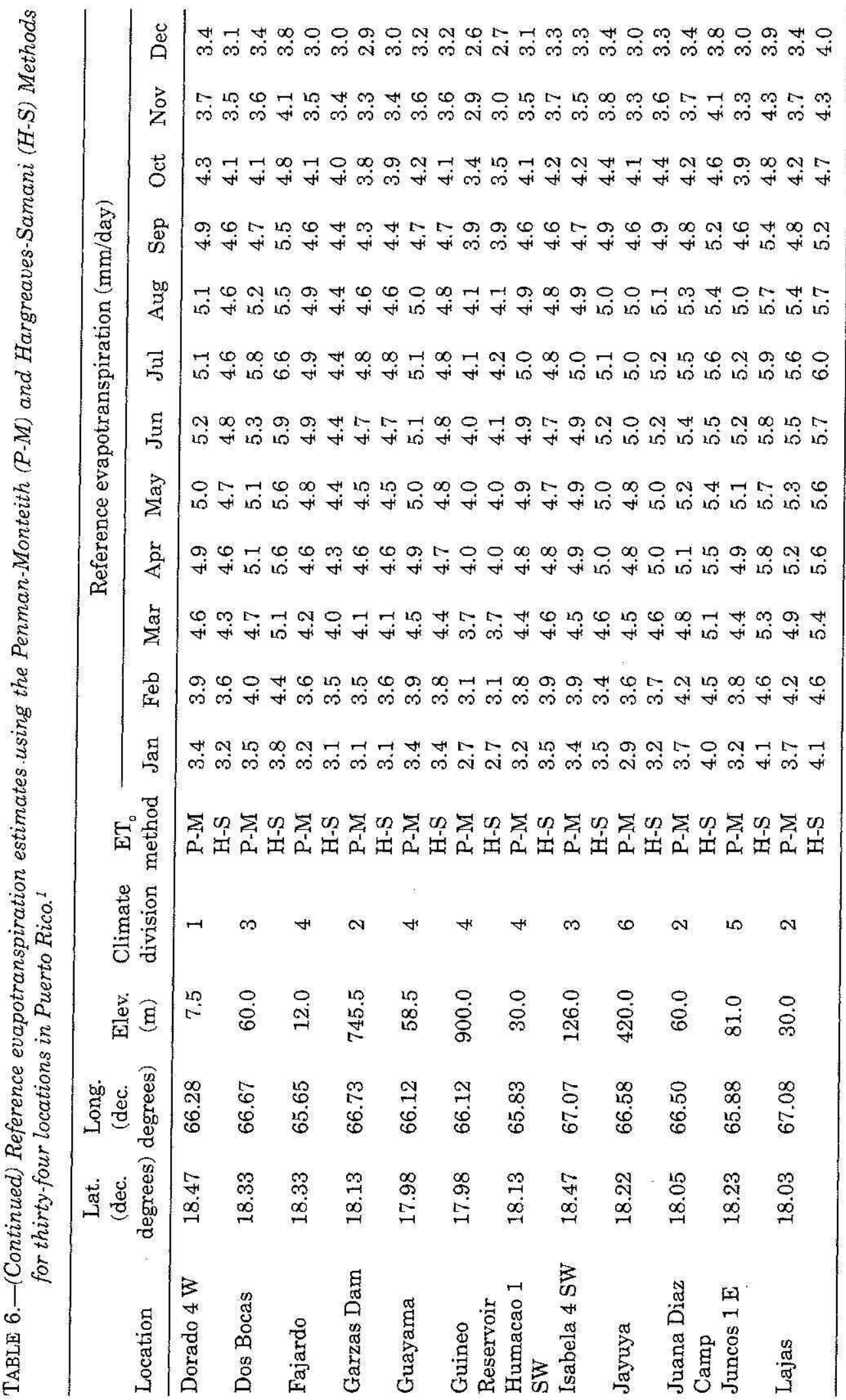


TABLE 6.-(Continued) Reference evapotranspiration estimates using the Penman-Monteith (P-M) and Hargreaves-Samani (H-S) Methods for thirty-four locations in Puerto Rico.'

\begin{tabular}{|c|c|c|c|c|c|c|c|c|c|c|c|c|c|c|c|c|c|}
\hline \multirow[b]{2}{*}{ Location } & \multirow{2}{*}{$\begin{array}{c}\text { Lat. } \\
\text { (dec. } \\
\text { degrees) }\end{array}$} & \multirow{2}{*}{$\begin{array}{l}\text { Long. } \\
\text { (dec. } \\
\text { degrees) }\end{array}$} & \multirow{2}{*}{$\begin{array}{l}\text { Elev. } \\
(\mathrm{m})\end{array}$} & \multirow{2}{*}{$\begin{array}{l}\text { Climate } \\
\text { division }\end{array}$} & \multirow{2}{*}{$\begin{array}{l}\mathrm{ET}_{0} \\
\text { method }\end{array}$} & \multicolumn{12}{|c|}{ Reference evapotranspiration ( $\mathrm{mm} /$ day) } \\
\hline & & & & & & Jan & Feb & Mar & Apr & May & Jun & Jul & Aug & Sep & Oct & Nov & Dec \\
\hline \multirow[t]{2}{*}{ Lares } & 28 & 66.88 & 360.0 & 6 & P-1 & 3.6 & 4.2 & 4.9 & 5.3 & 5.5 & 5.7 & 5.6 & 5.5 & 5.1 & 4.2 & 8 & 3.3 \\
\hline & & & & & & 3. & 4.4 & 5.1 & 5.5 & 5.7 & 5.8 & 5.8 & 5.6 & 5.4 & 4.5 & 4.2 & 3.7 \\
\hline \multirow[t]{2}{*}{ Maniti } & 18.43 & 66.45 & 75.0 & 1 & & 3. & 4.3 & 4.9 & 5.3 & 5.5 & 5.6 & 5.7 & 5.5 & 5.1 & 1.6 & 4.0 & 3.7 \\
\hline & & & & & $\mathrm{H}$ & 3. & 4. & 4.8 & 5.2 & 5.4 & 5.5 & 5.4 & 5. & 5.1 & 4.6 & 8 & 3.4 \\
\hline \multirow[t]{2}{*}{ Mayaguez } & 18.22 & 67.13 & 24.0 & 4 & $\mathrm{P}$ & 3. & 4. & 4.8 & 5.2 & 5.2 & 5.3 & 5 & 5 & 4.9 & 4.3 & 7 & 3.4 \\
\hline & & & & & & 3 & 4 & 5.2 & 5.6 & 5.7 & 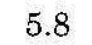 & & 5.6 & 5. & 4.7 & 4. & 3.8 \\
\hline \multirow[t]{2}{*}{ Patillas Dam } & 18.03 & 66.03 & 72.0 & 4 & P- & 3. & 3 & 4.4 & 4. & 4. & 4 & & & 4 & 4.0 & 4 & 3.1 \\
\hline & & & & & & 3. & 3 & 4. & 4. & 4. & 4 & 4 & 4 & 4 & 4.1 & 8 & 3.1 \\
\hline \multirow[t]{2}{*}{ Ponce $4 \mathrm{E}$} & 18.02 & 66.53 & 12.0 & 2 & F & 3 & 4 & 4. & 4. & 5. & 5 & $=$ & 5 & 4 & 4. & 3.6 & 3.3 \\
\hline & & & & & H & 3.8 & 4. & 4.8 & 5. & 5.7 & 5.1 & 5. & 5 & 5.0 & 4.5 & 4.0 & 3.7 \\
\hline \multirow[t]{2}{*}{ Quebradillas } & 18.47 & 66.9 & 111. & 1 & P-N & 3.7 & 4. & 4.9 & 5. & 5. & 5.3 & 5.3 & 5 & 5. & 4. & 4. & 3.7 \\
\hline & & & & & & 3.4 & 3. & 4. & 4.9 & 5.0 & 5.1 & 5.1 & 4.9 & 4.8 & 4.3 & 3.7 & 3.3 \\
\hline Ran & 18.50 & 67.13 & 71.1 & 1 & P-M & 3.2 & 3. & 4.2 & 4.5 & 4.7 & 4.8 & 4.9 & 4.9 & 4.6 & 4.1 & 3.5 & 3.1 \\
\hline Force Base & & & & & & 2.8 & 3 & 3. & 4. & 4. & 4. & 4.2 & 4 & 4 & 3.6 & 3.1 & 2.8 \\
\hline \multirow[t]{2}{*}{ Rio Piedras } & 18.40 & 66.07 & 30.0 & 3 & P-N & 3.3 & 3. & 4. & 4. & 4. & 5. & 5.0 & 5 & 4. & 4.0 & 3.4 & 3.2 \\
\hline & & & & & & 3.5 & 4.0 & 4. & 5. & 5. & 5. & 5.1 & 5.0 & 4. & 4.4 & 3.8 & 3.4 \\
\hline \multirow[t]{2}{*}{ San German } & 18.08 & 67.05 & 114.0 & 4 & P-M & 4.1 & 4.7 & 5.3 & 5. & 5. & 5.6 & 5.8 & 5.7 & 5 & 4.7 & 4.2 & 4.0 \\
\hline & & & & & H-S & 4.1 & 4.6 & 5.2 & 5.6 & 5.6 & 5.7 & 5.9 & 5.7 & 5.3 & 4.8 & 4.2 & 4.0 \\
\hline \multirow[t]{2}{*}{ Utuado } & 18.27 & 66.70 & 129.0 & 6 & P-M & 3.9 & 4.5 & 5.4 & 5.6 & 5.7 & 6.0 & 6.1 & 5.8 & 5.3 & 4.7 & 4.0 & 3.6 \\
\hline & & & & & $\mathrm{H}-\mathrm{S}$ & 4.2 & 4.8 & 5.6 & 5.9 & 5.9 & 6.2 & 6.2 & 5.9 & 5.7 & 5.1 & 4.4 & 4.0 \\
\hline
\end{tabular}

${ }^{1}$ Hargreaves-Samani (H-S) values of reference evapotranspiration were obtained from Goyal et al. (1988). 


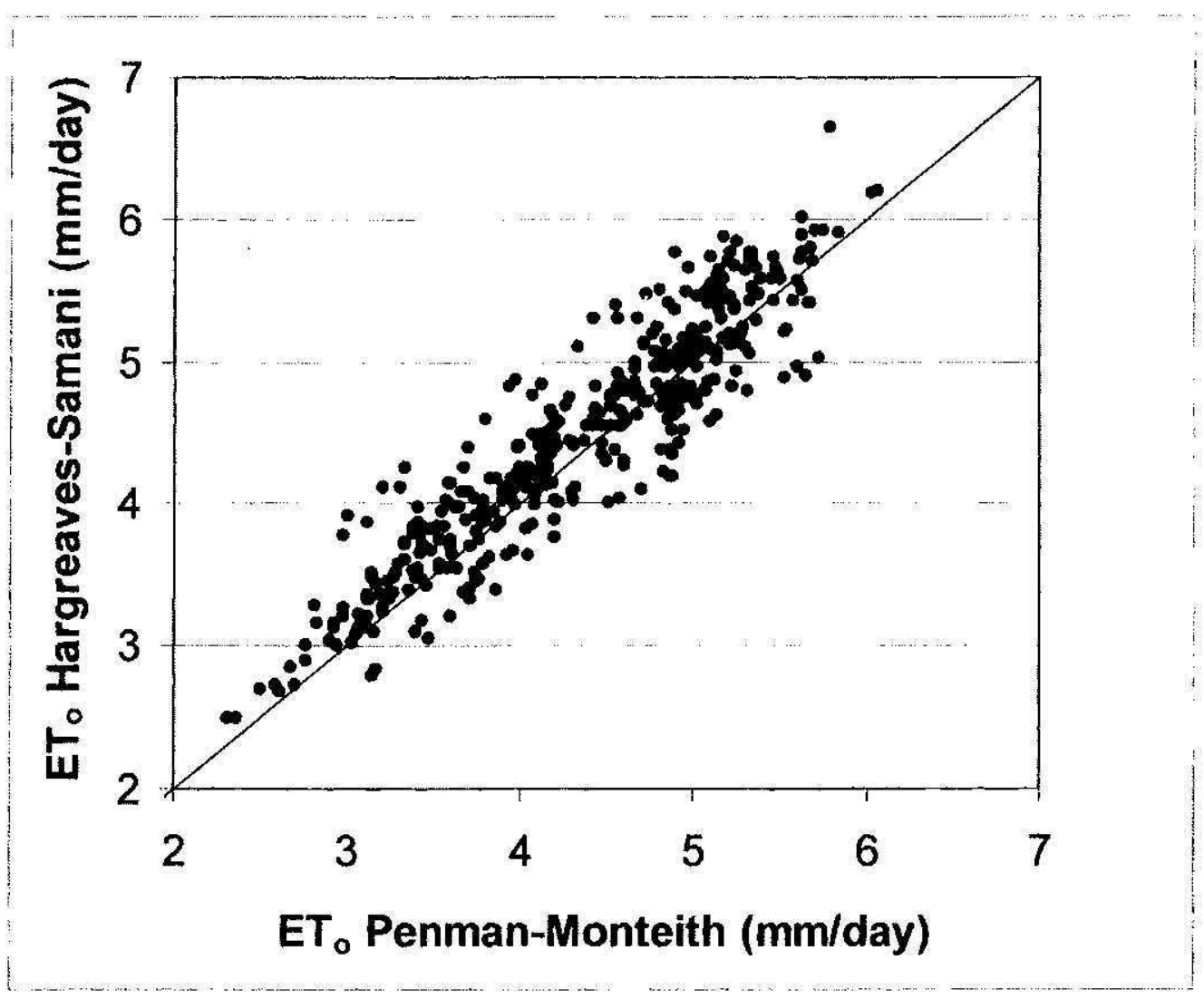

FIGURE 7. Compaxison of long-term average daily reference evapotranspiration (ET) estimated by the Penman-Monteith (P-M) and Hargreaves-Samani (H-S) Methods for each month for thirty-four locations in Puerto Rico.

derestimated $\mathrm{ET}_{0}$ at Aguirre. Juncos $1 \mathrm{E}$ is in Climate Division 5, which is humid, whereas Aguirre, in Climate Division 2, is semi-arid. The maximum underestimate of $-0.75 \mathrm{~mm} /$ day at Aguirre (semi-arid) is equal to a $13 \%$ error, and the maximum overestimate of $0.92 \mathrm{~mm} /$ day at Juncos $1 \mathrm{E}$ (humid) is equal to a $28 \%$ error. These results are consistent with the results of the ASCE study (Jensen et al., 1990), which found the Hargreaves-Samani method to underestimate on average by $9 \%$ in arid regions and overestimate on average by $25 \%$ in humid regions. It should be noted that Goyal et al. (1988) used estimated monthly values of $R_{a}$ based on a single latitude equal to 18 degrees, which may account for some of the differences. In this study, actual site latitudes were used to obtain $R_{a}$.

\section{Comparison of Peak Evapotranspiration Estimates}

Design of irrigation systems requires knowledge of the peak evapotranspiration (ET ${ }_{\text {peak }}$ ). The Soil Conservation Service (now known as 


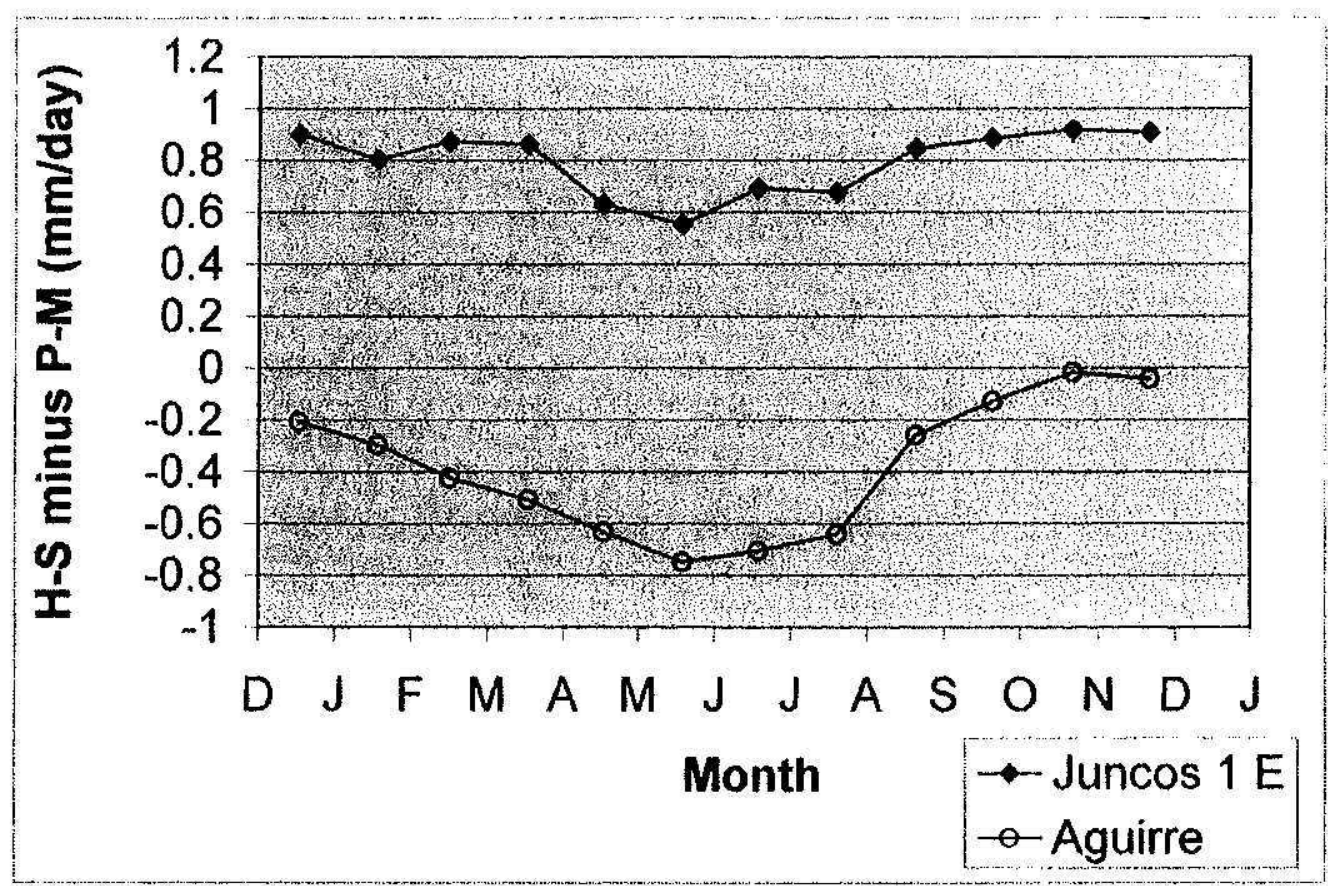

FIGURE 8. Estimated difference between reference evapotranspiration $\left(\mathrm{ET}_{\mathrm{o}}\right)$ calculated by the Hargreaves-Samani (H-S) and Penman-Monteith (P-M) methods at the Juncos $1 \mathrm{E}$ and Aguirre stations.

the Natural Resources Conservation Service) has published values of $\mathrm{ET}_{\text {peak }}$ for various crops grown in Puerto Rico in its Irrigation Guide (SCS, 1969). Another source of $\mathrm{ET}_{\text {peak }}$ is Goyal (1989), in which consumptive use estimates based on the SCS Blaney-Criddle method have been developed for fifteen vegetable crops. Irrigation system designers are using data from both of these sources in Puerto Rico at this time.

Table 7 compares $\mathrm{ET}_{\text {peak }}$ for six vegetable crops at three locations in Puerto Rico, obtained by using the SCS Irrigation Guide (SCS, 1969), the SCS Blaney-Criddle method (Goyal,1989) and the Penman-Monteith method. It should be noted that the SCS Irrigation guide recommends a single value of $\mathrm{ET}_{\text {peak }}$ for the entire island for a given crop. The peak ET for the SCS Blaney-Criddle method was obtained by using the maximum monthly consumptive use divided by the number of days in the month. The SCS Blaney-Criddle-estimates of $\mathrm{ET}_{\text {peak }}$ were not available for the Aibonito location. The input data for the Penman-Monteith-determined reference evapotranspiration were estimated by using the procedure described in this paper. Estimates of $\mathrm{ET}_{\text {peak }}$ were based on the maximum daily reference evapotranspiration $\left(\mathrm{ET}_{0}\right)$ times the published value of the crop coefficient $\left(\mathrm{K}_{\mathrm{c}}\right)$ for the mature (or mid) growth stage. The crop coefficients were obtained from Allen et al. (1998). 
TABLE 7.-Comparison of peak evapotranspiration estimates determined by three different methods for six vegetable crops at three locations in Puerto Rico.

\begin{tabular}{|c|c|c|c|}
\hline \multirow[b]{2}{*}{ Crop } & \multicolumn{3}{|c|}{ Peak evapotranspiration (mm/day) } \\
\hline & $\begin{array}{l}\text { SCS Irrigation Guide } \\
\text { for Caribbean Area }\end{array}$ & $\begin{array}{l}\text { SCS Blaney-Criddle } \\
\text { Method }^{2}\end{array}$ & $\begin{array}{l}\text { Penman-Monteith } \\
\text { Method }^{3}\end{array}$ \\
\hline & \multicolumn{3}{|c|}{ Fortuna } \\
\hline Cabbage & 4.1 & 5.3 & 6.1 \\
\hline Eggplant & 4.1 & 5.3 & 6.1 \\
\hline Cucumbers & 4.1 & 5.1 & 5.8 \\
\hline Melons & 4.1 & 4.8 & 5.8 \\
\hline Sweet Potatoes & 5.3 & 6.4 & 6.7 \\
\hline \multirow[t]{2}{*}{ Tomatoes } & 5.3 & 5.8 & 6.7 \\
\hline & \multicolumn{3}{|c|}{ Isabela } \\
\hline Cabbage & 4.1 & 5.1 & 5.7 \\
\hline Eggplant & 4.1 & 5.3 & 5.7 \\
\hline Cucumbers & 4.1 & 4.6 & 5.4 \\
\hline Melons & 4.1 & 4.6 & 5.4 \\
\hline Sweet Potatoes & 5.3 & 6.1 & 6.2 \\
\hline \multirow[t]{2}{*}{ Tomatoes } & 5.3 & 5.6 & 6.2 \\
\hline & \multicolumn{3}{|c|}{ Aibonito } \\
\hline Cabbage & 4.1 & NA & 5.5 \\
\hline Eggplant & 4.1 & NA & 5.5 \\
\hline Cucumbers & 4.1 & NA & 5.3 \\
\hline Melons & 4.1 & NA & 5.3 \\
\hline Sweet Potatoes & 5.3 & NA & 6.0 \\
\hline Tomatoes & 5.3 & NA & 6.0 \\
\hline
\end{tabular}

${ }^{1}$ From SCS, 1969. Technical guide for Caribbean Area, Section IV-Practice Standards and Specifications for Irrigation System, Sprinkler. Code 443. U.S. Department of Agriculture Soil Conservation Service.

${ }^{2}$ From Goyal M. R., 1989. Estimation of Monthly Water Consumption by Selected Vegetable Crops in the Semiarid and Humid Regions of Puerto Rico. AES Monograph 99-90, Agricultural Experiment Station, University of Puerto Rico Río Piedras, PR.

${ }^{3}$ Input to the Penman-Monteith equation for reference evapotranspiration were determined using the method described in this paper. Crop coefficients for the mature growth stage were obtained form Allen et al. (1998).

${ }^{4} \mathrm{NA}=$ Not Available.

For the three methods considered, estimates of $\mathrm{ET}_{\text {peak }}$ were, lowest to highest, as follows: SCS Irrigation Guide, the SCS Blaney-Criddle method and the Penman-Monteith method, respectively. The implications of these results are important because designers of irrigation systems in Puerto Rico may be under-designing systems at this time. Normally, an under-designed system can be compensated for by operat- 
ing the system longer; for example, a system could be operated for eight hours instead of six hours. However, if the system was designed to run more hours per day (e.g., 22 hours, which is the maximum recommended by the American Society of Agricultural Engineers, ASAE 1999), then increasing the operating time may not be an option.

\section{Method Limitations}

The approach presented in this paper should be considered only approximate for estimating reference evapotranspiration. Potential limitations include:

- The data presented in Tables 1,2 and 3 are valid only for Puerto Rico.

- The $\mathrm{r}^{2}$ values for the regression equations relating elevation and temperature in some cases were quite low, especially for minimum air temperature. Capiel and Calvesbert (1976) showed, for example, that Utuado at elevation $130 \mathrm{~m}$, located within an interior valley, had higher average temperatures during every month of the year than did Manatí at elevation $75 \mathrm{~m}$. The average temperature data for Utuado even exceeded average temperatures for Ponce (elevation $12 \mathrm{~m}$ ) for nine months of the year. Therefore, within interior valleys, long-term measured temperature data should be used if possible, rather than the temperature regression equations.

- The approach has not been validated using measured $\mathrm{T}_{\text {dew }}$ data from Climate Divisions 3, 5 and 6.

- Equation 4 has not been verified to be accurate for areas within Puerto Rico where elevations exceed $100 \mathrm{~m}$.

\section{CONCLUSION}

This study evaluated procedures for estimating climate data to be used as input to the Penman-Monteith reference evapotranspiration calculation method in Puerto Rico. Comparison of reference evapotranspiration based on estimated and measured data showed reasonably good agreement. An example was given to illustrate the use of the proposed climate parameter estimation procedure for Dos Bocas, PR. Estimates of reference evapotranspiration calculated with the Penman-Monteith method were compared with estimates made with the Hargreaves-Samani method for thirty-four locations in Puerto Rico. Maximum positive and negative differences between the two methods 
( $\mathrm{H}-\mathrm{S}$ minus P-M) were 0.92 and $-0.75 \mathrm{~mm} /$ day, respectively. Estimates of peak evapotranspiration by the SCS Irrigation guide, SCS BlaneyCriddle method and the Penman-Monteith method were compared for five vegetable crops at three locations in Puerto Rico. The PenmanMonteith method produced higher estimates of peak evapotranspiration than the other two methods, suggesting that irrigation systems are possibly being under-designed in Puerto Rico at this time. The methods described in this paper can be used to estimate reference evapotranspiration at any location within Puerto Rico. It is evident from this study that additional long-term climate data are needed in Puerto Rico, especially in the interior mountain regions of the island.

\section{LITERATURE CITED}

Allen, R. G., L. S. Pereira, D. Raes and M. Smith, 1998. Crop Evapotranspiration Guidelines for Computing Crop Water Requirements. FAO Irrigation and Drainage Paper 56, Food and Agriculture Organization of the United Nations, Rome.

ASAE, 1999. Design and Installation of Microirrigation System. American Society of Agricultural Engineers, ASAE EP405.1 DEC99.

Capiel, M. and R. J. Calvesbert, 1976. On the climate of Puerto Rico and its agricultural water balance. J. Agric. Univ. P.R. 60(2):139-153.

Choisnel, E., O. De Villele and F. Lacroze, 1992. "Une approache uniformisée du calcul de l' évapotranspiration potentielle pour l'ensemble des pays de la Communauté Européenne." Com. Commun. Européennes, EUR 14223 FR, Luxembourg, 176 pp.

Clarke, D., 1998. CropWat for Windows: User Guide. Version 4.2.0013.

Goyal, M. R., E. A. González and C. Chao de Baez, 1988. Temperature versus elevation relationships for Puerto Rico, J. Agric. Univ. P.R. 72(3):440-467.

Goyal, M. R., 1989. Estimation of Monthly Water Consumption by Selected Vegetable Crops in the Semiarid and Humid Regions of Puerto Rico. AES Monograph 99-90, June, Agricultural Experiment Station, University of Puerto Rico, Río Piedras, PR.

Hargreaves, G. H. and Z. A. Samani, 1985. Reference Crop Evapotranspiration from Temperature. Appl. Eng. Agric., ASAE. 1(2):96-9.

Harmsen, E. H., J. Caldero and M. R. Goyal, 2001. Consumptive Water Use Estimates for Pumpkin and Onion at Two Locations in Puerto Rico. Proceedings of the Sixth Caribbean Islands Water Resources Congress. Editor: Walter F. Silva Araya. University of Puerto Rico, Mayagüez, PR 00680.

Jensen, M. E., R. D. Burman and R. G. Allen, 1990. Evapotranspiration and irrigation water requirements. ASCE Manuals and Reports on Engineering Practice No. 70.332 pp.

National Climate Data Center, 1992. International Station Meteorological Climate Summary (ISMCS), Version 2.

SCS, 1969. Technical guide for Caribbean Area, Section IV-Practice Standards and Specifications for Irrigation System, Sprinkler. Code 443. U.S. Department of Agriculture Soil Conservation Service. 